\title{
TRADITION FORMATION OF WATER CIVILIZATION IN UZBEKISTAN
}

\author{
Doctoral student of TIIAME "Department of Humanities" \\ Khatamova Ra'no \\ xatamovar16@gmail.com
}

\begin{abstract}
:
This article summarizes issues related to water civilization, irrigation thinking and centuries-old traditions of our people on irrigation, agriculture and land reclamation as the basis for the formation of the Tashkent Institute of Irrigation and Agricultural Mechanization Engineers at the beginning of the 20th century. It is known that the natural foundations of the water civilization of our region are inextricably linked with the history and development of the largest rivers in Central Asia, the Syrdarya and Amudarya, life in their basins, human activities and society in this region.

Keywords: centuries-old traditions, spirituality, education and upbringing, irrigation and agriculture, water, civilization in Uzbekistan.

Article Received: 18 October 2020, Revised: 3 November 2020, Accepted: 24 December 2020
\end{abstract}

\section{Introduction}

Ever since human society began to live on Earth as an important part of human history, all generations of humanity, as owners of aquatic civilization formed over the centuries, have been in constant interaction with this gift of nature and have been constantly using its potential. As society develops and techniques and technologies improve, the scope of human impact on nature is expanding, and significant changes are taking place in the environment of aquatic civilization and irrigated agriculture. This, in turn, makes the development of the need for training in the field of water civilization and irrigation in today's world interconnected and interconnected, making it important to have a certain level of knowledge, skills and abilities in this field.

Undoubtedly, the antiquity of the formation of water civilization and its unique traditions in the territory of our country is explained by the fact that humanity is well aware of the existence of life where there is water. After all, the availability of natural water supplies ensures the evolution of life on our planet.

\section{Materials:}

The role of natural rivers and water basins, especially the Amudarya and Syrdarya, in the emergence and development of agricultural culture in the Central Asian region is of great importance. Therefore, the scientific study of this problem is not new to science. In Uzbekistan, too, the analysis of this topic from a purely scientific point of view has long been an interesting topic for orientalists, historians, ethnographers, art critics, archeologists, architects. V.L.Vyatkin (1927), M.E.Masson (1935), V.V.Bartold (1965), Ya.G'ulomov (1957), A.B.Boboxonov (1959), A.Muhammadjonov $(1967,1972)$ and the resulting works. ${ }^{1}$

This aspect of the problem was formed as a result of many years of research by A. Nizomov, and most of the scientific data was collected through the observation of ancient hydraulic structures in nature. 2008, - p. 236). First of all, it should be noted that in the play the author tried to reveal the deep faith of our ancient generations in water, its conservation, as well as ways to use it economically and economically. In this regard, we also consider it important to note that the book has served as a specific scientific source to clarify our understanding of the concept of "water civilization".

\footnotetext{
${ }^{1}$ Nizomov "O'zbekistonning qadimgi gidrotexnik inshootlari geografiyasi ( - T.: Gidrogeologiya va injenerlik geologiyasi institute (GIDROINGEO)", 2008, page 3.
} 
It is known that the natural foundations of the water civilization of our region are inextricably linked with the history and development of the largest rivers in Central Asia, the Syrdarya and Amudarya, life in their basins, human activities and society in this region. The Amudarya is the wettest river in Central Asia, with a length of $1415 \mathrm{~km}$. The upper reaches of this river begin with the glaciers on the northern slopes of the Hindu Kush, and are joined by the Pamirs, which flow from the mountain lake Zorkol. The place where the tomato joined was called "Vohondaryo". The Amudarya was called Panj until the next tributary, the Vakhsh. This river, which flowed through the majestic mountains, flowed with it, muddying many mineral rocks. Then, along the Panj River, it flows into a smooth valley with a width of $\mathrm{km}$, where it spreads and forms an island called Ortutoqay. After crossing the plain, the river narrows and is joined on the left by the Kokcha River, which begins at the glaciers in the central part of the Hindu Kush in Afghanistan. From here the Panj River flows 70 $\mathrm{km}$ to the plain, where the Vakhsh River joins Panj on the right. Then it takes the name of Amudarya and flows along the plain, and is joined by Kofirnikhan and Surkhan on the right and Kunduzdarya on the left. Surkhandarya is the last tributary of the Amudarya, after which it flows without any tributaries. ${ }^{2}$

The Enisei-Ket languages, widespread in Central Asia, became widespread by the second millennium BC. Some researchers speculate that it may be related to the Enisei-Ket languages (meaning "Mother Water"). The Turkic peoples called the Amudarya "Ukuz". Named "Ukuz" by the Sak-Massagets, a local tribe of the Amudarya, the river has been preserved for centuries. To the Greeks and Persians, the term "Ukuz" was changed to "Oxus", meaning "Ox", depending on the spelling.

\footnotetext{
${ }^{2}$ G'ulomov Y.G ., Xorazmning sug'orilish tarixi. Qadimgi zamonlardan xozirgacha. - Toshkent, 1959, - page 19-20.
}

It is possible that the term Oks is derived from the Turkish word Aksu (Aksuv). ${ }^{3}$ In medieval sources, this river occurs in the form of Jayhun, Amul, Amu. Hence, it can be said that Ukuz Amudarya is a common name among the local Turkic peoples. ${ }^{4}$

About 22,000 years ago, the formation of the Amudarya River began in the middle of the New Paleolithic and the end of the Holocene. The importance of the Amudarya in the region is still great today and plays an important role in the development of water civilization and irrigated agriculture in the region.

The tributaries of the Syrdarya River also play an important role in the development and improvement of water civilization in the Tashkent and Fergana oases. Syrdarya has been called by different names since historical times. Ancient Greek sources state that it was named Tanais and flowed into the same river as the Oxus-Amudarya, and that the distance between these rivers was 240 stadiums (80 parsangs). The lower reaches of the river and the Aral Sea are called "Sir". The term means "watery river" in the Saxon language and "turning point of the river" in Turkish. The Arab peoples called this river the Sayhun River. In medieval historical sources, this river is called "Shoshsuvi", "Khojandsuvi", "Uzgandasuvi".

In general, these two major rivers played a major role in the formation of sedentary farming culture in the Central Asian region. Surkhandarya, Kashkadarya, Zarafshan, Chirchik and other similar rivers, which are tributaries of the Syrdarya and Amudarya rivers, also played an important role in the formation of aquatic civilization in the formation of irrigated agriculture.

This means that in the territory of Uzbekistan since ancient times formed a unique water civilization and culture of irrigated agriculture, in

\footnotetext{
${ }^{3}$ Mahmud Kashgari. Office of Turkish words (Devonu lugotit turk) / 3 volumes. Translator and publisher S.M. Mutallibov. - Tashkent: Fan, 1960. 1 Vol. - p. 91,411. ${ }^{4}$ G'ulomov Y.G ., Xorazmning sug'orilish tarixi. Qadimgi zamonlardan xozirgacha. - Toshkent , 1959, - page 37-38..
} 
which the Surkhandarya and Kashkadarya rivers and their tributaries play an important role. The Kashkadarya basin is one of the largest rivers in South Sogd, which is a formed area of sedentary water civilization. This oasis was divided into two large provinces in ancient times. These lands, named in Greek sources as Ksenipa and Nautaka, were named Kesh and Naxhab in later sources. ${ }^{5}$

Along with Bukhara and Samarkand, the ancient Kashkadarya oasis was also part of Sogdiana. Its borders correspond to the territory of ancient South Sogdia. The water source of this oasis is known as Kashkadarya. The second largest water source is called Yakkabogdarya (Kyzyldarya). This river divides into two streams near the old Yakkabog, Karabakh (in the western direction) and Kizilsuv (in the North-West direction), and the Red Water joins the Tankhozdarya near the village of Ortakurgan. Another important source of water in the oasis is the Guzardarya, which is a left tributary of the Kashkadarya in ancient times. ${ }^{6}$

These findings confirm that small streams and springs flowed in the mountainous and foothill areas of the eastern part of the oasis, proving that these water resources were formed from rivers.

It is known that in ancient times a large canal $200 \mathrm{~km}$ long was dug from the Zarafshan River to irrigate the low-water Karshi oasis. Undoubtedly, this also contributed to the development of water civilization and irrigated agriculture in the oasis. These facts testify to the formation of aquatic civilization and irrigated agriculture in the oasis.

The rivers that are tributaries of the Syrdarya, the Angren and Chirchik rivers, played an important role in the formation and development

\footnotetext{
${ }^{5}$ Askarov A. Ancient agricultural culture of the Bronze Age in the south of Uzbekistan. - Tashkent: Fan, 1977; Shaydullaev Sh.B. Northern Bactria during the early Iron Age. - Tashkent, 2000.

${ }^{6}$ Lunina S. B. Cities of South Sogd in the VII-XII centuries. T .: Fan, 1984 . - page 11-12.
}

of irrigated agriculture in the ancient Chach oasis, on the basis of which the urban culture. ${ }^{7}$

In the development and improvement of aquatic civilization, the Amudarya, Syrdarya and its tributaries have laid the foundation for the gradual polishing of irrigated agriculture. In the process of spreading irrigated farming centers to the valleys of large rivers and their tributaries, the cultural impact of economic and cultural ties and population migration from the territory of southern Turkmenistan, the first center of irrigated agriculture, to the central parts of Central Asia played an important role. ${ }^{8}$

The development of the major river basins in Central Asia during the Bronze Age allowed for the spread of sedentary farming culture and aquatic civilization to the northeast of the region. This period was the period of the use of iron ore, the beginning of the manufacture of weapons from iron weapons. ${ }^{9}$

At the beginning of the first millennium $\mathrm{BC}$, the first iron products appeared in Central Asia, and the beginning of the use of iron and its gradual spread to the region dates back to the $\mathrm{X}$-VI centuries BC.

During this period, the emergence of iron metallurgy in the valleys of major rivers in the region allowed for the widespread spread of irrigated agriculture. The role of irrigated agriculture, which has become the main branch of the society's economy, has become the main link of the society's economy, which in turn has contributed to the development of trade and handicraft culture.

\footnotetext{
${ }^{7}$ Mukhammadzhanov A.R. Towards the history of irrigation in the Kushan era. In the book. Central Asia in the Kushan era. T. 3. - Moscow: Nauka, 1975 .-- P. 279.

${ }^{8}$ Мавлонов У. М. Ancient ways of Central Asia: stages of formation and development. - Tashkent: Academy, 2008. p. 218.

${ }^{9}$ Masson V.M- Ancient agricultural culture of Margiani // MIA. -Ka 73.-M.-L., 1959; Sagdullaev A.S. Notes on the early Iron Age of Central Asia // SA, - 1982. -Xa 2; The most ancient states of the Caucasus and Central Asia ... - pp. 179180
} 
Another important feature of this period was the formation of a number of historical and cultural regions in Central Asia (Khorezm, Bactria, Margiana, Sogdiana, Fergana, Chach), some of which were attached to the associations of major powers (Ancient Bactria, Ancient Khorezm).

During this period, the improvement of nomadic animal husbandry and changes in socio-economic life were different from previous historical periods. In the territory of Central Asia, another important factor of that period, a number of historical regions, such as Khorezm, Bactria, Margiana, Sogdiana, Fergana, Chach, flourished. Such an early state structure based on artificial irrigation played an important role in the formation of agricultural culture.

\section{Methods:}

The following factors can be considered in the rapid development of the culture of irrigated agriculture in our region in the VI century AD and the improvement of the first culture of irrigated agriculture. These are:

- Natural-geographical and social factors influencing the emergence of irrigated agriculture; - conditions in the places where the first agricultural culture appeared;

- distribution of primary crops;

- methods of tillage and artificial irrigation;

- Effective establishment of agriculture adapted to the irrigation system.

The names of settled agricultural oases in Uzbekistan and neighboring countries are mentioned. Among them are Nautaka, Ksenippa in the Kashkadarya oasis, Zarafshan oasis in the city of Maraganda, the capital of Sogdiana, and others.

The Zarafshan River is recorded in Greek sources as Politimet, and the canals taken from it show that the fertile lands of the oasis were irrigated and a lot of agricultural products were grown. ${ }^{10}$

\footnotetext{
${ }^{10}$ Arrian. Alexander's Campaign / Translated from Greek by M.L. Sergeenko. - M.-L., 1962.
}

Further research shows that in recent years, the agricultural culture in the Sogdiana region dates back to ancient times. On the mountain slopes of the Gissar Mountains there are fields of wild barley and wheat, the natural conditions of which have long been the basis for the formation of agriculture, including grain, in the oasis.

Kuchuktepa, Bandikhan and Kyzyltepa (Surkhandarya oasis), Sangirtepa, Uzunqir, Daratepa and Erkurgan (Kashkadarya oasis), Afrosiyob and Chokalvar, Koktepa (Varafshan), Koktepa (Zarafshon), the centers of water civilization, trade and handicrafts and sedentary farming oases. ) should be mentioned. Among the handicrafts and labor tools found in these monuments, the tools used by the oldest farmers are noteworthy. ${ }^{11}$

At that time, the first blacksmithing industry, which was an important stage of the region's economy, was important. Sedentary farming and cattle-breeding are widespread in the oases. From large-hoofed domestic animals, farmers introduced the method of plowing the land by tying a pig to a plow while plowing the land. Historical facts prove that this period was preserved until the beginning of the XX century.

During the Bronze Age, the cattle-breeding population lived semi-settled in the steppes and mountains of Central Asia. As a result of the increase in the number of domestic animals, cattle-breeding developed, and the increase in the number of cattle had to find large pastures and large meadows. Towards the last years of the Bronze Age, the tribes engaged in cattle-breeding switched to pastoralism, that is, the way of feeding their cattle.

As a result of the development of new pastures, by the early Iron Age, nomadic pastoralism

\footnotetext{
${ }^{11}$ Askarov A. Sapallitepa. - Tashkent: Fan, 1973; Askarov A. Ancient land culture of the Bronze Age in the south of Uzbekistan. - Tashkent: Fan, 1977; Askarov A / Eng kadimgi shahar. - Toshkent: Manaviyat, 2001; Askarov A.A., Abdullaev B.N. Dzharkutan (on the problem of proto-urban civilization in the south of Uzbekistan). - Tashkent: Fan, 1981
} 
emerged, which covered a relatively large area from pastoralism.

Processes like this have also led to the gradual expansion of aquatic civilization. Nomadic pastoralists in the early Iron Age were highly involved in horse breeding and sheep breeding. Another important sector of the region's economy is mining. Livestock breeders, who have extensively developed copper deposits in Central Asia and Kazakhstan, have made another major discovery. The discovery of this iron ore smelting took place in BC. developed considerably by the beginning of the millennium. People began to make iron, weapons, household utensils from it.

We all know that the Amirabad culture was formed in the lands of ancient Khorezm from the first millennium BC. It develops extensively at the same time as the changes in the social life of the period. It was found that the union of the Massaget tribes was a dominant period, during which time there were frequent clashes among the Sak tribes living in the foothills of the Ox-Yaksart basin. Herodotus' account of the expulsion of some of the Scythians to southeastern Europe by the Massagets (Herodotus, History, IV. II) shows that the union of the Massagets intensified and that large political associations were formed with Khorezm as its center.

We all know that the Amirabad culture was formed in the lands of ancient Khorezm from the first millennium BC. It develops at the same time as the changes in the social life of this period. In the Ox-Yaksart Basin, there were frequent clashes between the Sak tribes living on the slopes. Herodotus says that the Scythians were squeezed into southeastern Europe by the Massagets (Herodotus, History, IV.II). At that time, the Maggaget tribe became stronger and took Khorezm as its center, and this process led to the emergence of huge political associations.

Result: There are no large monuments built on the land in the ancient irrigated lands, ie in the Khorezm region. However, there is evidence that two-bladed flat bushings, the base side of which were found to have arrowheads. The great thinker Beruni noted that the water supply of ancient Khorezm flowed into the depths of the main river Amudarya "Sariqamish" before the emergence of this region. According to him, the Amudarya changed its course and flowed through a stream called "Mazdubast" between Khorezm and Jurjan, which flowed in the direction of "Karakum". There were villages and auls along this river for a long time. Later, these villages and auls began to suffer. As a result, they moved to the Caspian Sea. These peoples were Alon and Oslar. The popular language of the Alonians was Khorezm, which was a mixture of Bijdon.

Conclusion: So, we all know that the existence of life on our mother planet, Earth, and the existence of humanity on it is one of the greatest miracles. Therefore, the importance of carefully preserving life and the non-living nature that provides it, including water, is immeasurable. Mankind, who is considered to be the most prosperous of all living beings, is at the top with his intellect and thinking.

This means that the human being is an integral part of both nature and society at the same time. In this regard, in order to study the current problems, to take an active part in the implementation of work related to the conservation of water, everyone should have a broad understanding of this. At the same time, it shows the importance of understanding the responsibility of each of us in the protection of Mother Nature, husband and water, and in the scientific and practical solution of the problems that arise in this process.

\section{Bibliography}

[1] The Constitution of the Republic of Uzbekistan. - T .: Uzbekistan, 2015

[2] The Law "On the Fundamentals of State Policy on Youth in the Republic of Uzbekistan" adopted in 2016 in the new edition. $\quad-\mathrm{T} \quad . \quad$ Collection of legal documents of the Republic of Uzbekistan, 2016. 
[3] Decree of the President of Uzbekistan dated July 5, 2017 "On increasing the effectiveness of state policy on youth and supporting the activities of the Youth Union of Uzbekistan." http://akadmvd.uz/wp-content/uploads... http://akadmvd.uz 14 Nov 2019

[4] Decree of the President of the Republic of Uzbekistan "On the strategy of actions for further development of the Republic of Uzbekistan".

http://el.tfi.uz/images/Nizomov_MD_uz_ ... http://el.tfi.uz 14 Nov 2016

[5] Resolution of the President of the Republic of Uzbekistan dated May 8, 2018 "On measures to radically improve the system of training of engineering and technical personnel for agriculture and water management." - People's speech, May 9, 2018

[6] Resolution of the President of the Republic of Uzbekistan dated May 24, 2017 "On measures to radically improve the system of training higher education at the Tashkent Institute of Irrigation and Agricultural Mechanization Engineers." People's speech, May 25, 2018

[7] Karimov IA Uzbekistan on the Threshold of the 21st Century: Threats to Security, Conditions of Stability and Guarantees of Development. - T .: Uzbekistan, 1997

[8] Karimov IA High spirituality is an invincible force. $\quad-\mathrm{T} .:$ "Spirituality", 2008.

[9] Mirziyoev Sh.M. We will build our great future together with our brave and noble people. -Tashkent, Uzbekistan, 2017. $488 \mathrm{p}$.

[10] Mirziyoev Sh.M. The rule of law and the protection of human interests are the key to the country's development and the wellbeing of its people. -Tashkent, Uzbekistan, 2017.
[11] Mirziyoev Sh.M. From the national revival to the national upsurge. - $\mathrm{T}$.: NMIU "Uzbekistan", 2020. - 488 p.

[12] Speech of the President of the Republic of Uzbekistan Sh.M.Mirziyoev at the 72nd session of the UN General Assembly // http:/uz24.uz/uz/politics/ shavkatmirziyoyev-speech at the $72 \mathrm{nd}$ session of the UN General Assembly.

[13] Speech by the President of the Republic of Uzbekistan Shavkat Mirziyoyev at the 75th session of the General Assembly of the United Nations on September 25, 2020. - "People's Word" newspaper, September 26, 2020

[14] Abu Rayhan Beruni. Selected works. - T $\therefore$ Fan, 1968. Tashkent. II. Avesto. A. Close translation. - T $\therefore$ G. Ghulam Publishing House, 2001.

[15] Andrianov BV Ancient orositelnye systems Priaralya - M .: Nauka, 1969

[16] Askarov A. Ancient culture of the Bronze Age of South Uzbekistan. - Tashkent: Fan, 1977

[17] Askarov A. Sapallitepa. - Tashkent: Fan, 1973

[18] Askarov AA, Abdullaev BN Dzharkutan (on the problem of Proto-Russian civilization in the south of Uzbekistan). Tashkent: Fan, 1981.

[19] Askarov A. The most ordinary city. Tashkent: Manaviyat, 2001

[20] Azamov A. Under the name of Ahmad alFarghani // Journal of World Literature. 1998. - № 3.

[21] Baratov P. Natural geography of Uzbekistan. - T .: Teacher, 1996.

[22] Baratov L., Kholmatov K. The economic importance of the rivers of Central Asia. $\mathrm{T}$.: Uzbekistan, 1981.

[23] Bertels E.. E.. Excerpts from the Avesta // Collection "East". - M: Gosizdat, 1924. Kn. 4.

[24] Beckett P., Roy J. Qanats around Kirman // Centr.-Asian Soc. - 1953. - № 40. 
[25] ButlerM.Л. Irrigation in Persia by qanats // Civil Engineering. - 1933. - № 3 (2).

[26] Bukinich. D.D. Brief preliminary information on water supply and irrigation of Old Termez and its region. // Trudy AN UzSSR, ser. I, history, archeology, issue. 2. - Tashkent, 1940

[27] Buryakov Yu.F. Genesis and stages of development of urban culture of the Tashkent oasis. -Tashkent., 1982.

[28] Dzhurakulov MD .. Kholmatov NU Mesolithic and Neolithic Middle Zerafshan, - Tashkent: Fan, 1991 